\title{
PELAKSANAAN PERJANJIAN SEWA -MENYEWA KEBUN DI DESA POMPENGAN KECAMATAN LAMASI TIMUR TINJAUAN EKONOMI ISLAM
}

\author{
H. Muammar Arafat Yusmad \\ Fakultas Syariah Institut Agama Islam Negeri (IAIN) Palopo \\ Email : muammar_arafat@iainpalopo.ac.id

\section{Puspa}

Fakultas Ekonomi dan Bisnis Islam Institut Agama Islam Negeri (IAIN) Palopo

\begin{abstract}
It is undeniable that leasing transactions are common in the community. Renting is basically permissible in Islam, because basically human beings are always constrained by limitations and shortcomings. Therefore, humans between one and the other are always bound and need each other, and renting is one of the applications of limitations that are needed by humans in social life. However, if viewed from the nature of speculative renting a garden, it means that there is no certainty whether the plantation will succeed or not at all produce in large or small quantities, then this element of uncertainty cannot be justified in Islamic law.
\end{abstract}

Keywords : Leasing

\begin{abstract}
Abstrak
Tidak dapat dipungkiri bahwa transaksi sewa menyewa sudah lazim dilakukan di masyarakat. Sewa menyewa pada dasarnya diperbolehkan dalam Islam, karena pada dasarnya manusia senantiasa terbentur pada keterbatasan dan kekurangan. Oleh karena itu, manusia antara yang satu dengan yang lainnya selalu terikat dan saling membutuhkan, dan sewa menyewa adalah salah satu aplikasi keterbatasan yang dibutuhkan manusia dalam kehidupan bermasyarakat. Namun jika dilihat dari sifat sewa-menyewa kebun yang spekulatif, artinya tidak adanya kepastian apakah kebun tersebut akan berhasil atau tidak sama sekali menghasilkan dengan jumlah yang banyak atau sedikit, maka unsur ketidakpastian seperti ini tidak dapat dibenarkan dalam hukum Islam.
\end{abstract}

Kata Kunci: Perjanjian sewa menyewa

\section{PENDAHULUAN}

Sebagai makhluk sosial, manusia menerima dan memberikan andilnya kepada orang lain, saling berinteraksi untuk meme-nuhi kebutuhannya dan mencapai kemajuan dalam hidupnya. Setiap manusia yang ber-ada dimuka bumi ini perlu bantuan orang lain khususnya untuk memenuhi kebutuhan-nya yang setiap hari semakin bertambah. Oleh karena itu, ekonomi Islam meng-adakan aturan-aturan bagi keperluan manu-sia 
dan membatasi keinginannya hingga memungkinkan manusia memperoleh kebutuhannya tanpa memberi mudharat kepada orang lain dan mengadakan hukum tukar menukar keperluan antara anggota masya-rakat dengan jalan yang adil, agar manusia dapat melepaskan dirinya dari kesempitan dan memperoleh keinginannya tanpa merusak kehormatan. ${ }^{1}$

Ada banyak bentuk kegiatan manusia yang telah diatur oleh agama, salah satunya adalah sewa-menyewa. Sewa menyewa pada dasarnya adalah penukaran manfaat sesuatu dengan jalan memberikan imbalan atau jasa dalam jumlah tertentu. Pada dasarnya sewa-menyewa merupakan penukaran manfaat barang yang telah jelas wujudnya tanpa menjual 'ain dari benda itu sendiri.

Menurut ulama Hanafiyah, sewa-menyewa adalah akad atau transaksi ter-hadap manfaat dengan imbalan. Menurut ulama Syafi'iyah, sewa-menyewa adalah transaksi terhadap manfaat yang dikehen-daki secara jelas harta yang bersifat mubah dan dapat dipertukarkan dengan imbalan tertentu.

Menurut ulama Malikiyah dan Hana-bilah, sewa-menyewa adalah pemilikan manfaat suatu harta benda yang bersifat mubah selama periode waktu tertentu dengan suatu imbalan. ${ }^{2}$

Sewa-menyewa merupakan suatu kegiatan untuk mendapatkan manfaat atas suatu barang tanpa mengurangi zat atas suatu barang. Definisi yang hampir sama juga disampaikan Abdul Aziz Dahlan, sewa-menyewa merupakan suatu transaksi atas suatu manfaat barang yang disewakan. Sehingga dalam akad sewa-menyewa yang menjadi milik penyewa adalah manfaat atas suatu barang. ${ }^{3}$ Bentuk transaksi sewa menyewa ini dapat menjadi solusi bagi pemenuhan kebutuhan manusia, karena keterbatasan keuangan yang dimilikinya manusia tetap dapat memenuhi kebutuhan-nya tanpa melalui proses pembelian atau penjualan. Selain sebagai kegiatan mиa-malah, sewa-

\footnotetext{
${ }^{1}$ Nazar Bakry, Problematika Pelaksanaan Fiqh Islam, Jakarta: PT. Raja Grafindo Persada, 1994, h. 57.

${ }^{2}$ Ghufron A. Mas'adi, Fiqh Muamalah Kontekstual, Jakarta: PT. Raja Grafindo Persada, 2002, h. 182.

${ }^{3}$ Abdul Aziz Dahlan, Ensiklopedi Hukum Islam, Jakarta: PT. Ichtiar Baru Van Hoeve,1996, h. 660.
} 
menyewa juga mempunyai fungsi tolong-menolong dalam pemenuhan kebutuhan manusia yang tidak terbatas sifatnya. Namun demikian, tidak semua harta benda boleh diakadkan sewa-me-nyewa, kecuali yang memenuhi persyaratan berikut ini ${ }^{4}$ :

1. Manfaat benda dapat dipahami dan dikenal.

2. Obyek sewa-menyewa dapat diserahkan sebagaimana penyerahan harga (ada serahterima).

3. Obyek sewa-menyewa dapat dimanfaat-kan sampai kepada masa yang disepakati.

4. Penyerahan manfaat obyek sewa harus sempurna yakni adanya jaminan kese-lamatan obyek sewa sampai kepada masa yang disepakati.

Akad sewa-menyewa merupakan akad pengambilan manfaat sesuatu benda, maka syarat kemanfaatan obyek sewa harus menjadi perhatian oleh kedua belah pihak. Manfaat barang yang disewakan harus jelas dan dapat dimanfaatkan oleh penyewa (musta'jir) sesuai dengan kegunaan barang tersebut, seandainya barang tersebut tidak dapat digunakan sebagaimana yang diper-janjian maka perjanjian sewa-menyewa itu dapat dibatalkan. Manfaat obyek sewa juga harus manfaat langsung dari benda tersebut, tidak dibenarkan sewa-menyewa manfaat suatu benda yang bersifat tidak langsung (turunan). Kemanfaatan obyek sewa harus-lah barang yang dibolehkan dalam agama, perjanjian sewa-menyewa barang yang ke-manfaatannya tidak dibolehkan oleh keten-tuan hukum agama adalah tidak sah dan wajib untuk ditinggalkan, misalnya perjanjian sewa-menyewa rumah untuk diguna-kan sebagai tempat prostitusi, atau menjual minuman keras serta tempat perjudian, demikian juga memberikan uang kepada tukang ramal. ${ }^{5}$

Sewa-menyewa dalam kehidupan masyarakat bukan lagi menjadi hal yang baru, akan tetapi sudah hal yang lazim dilakukan oleh masyarakat, khususnya

\footnotetext{
${ }^{4}$ Abi Abbdullah Muhammad bin Idris Asy-Syafi'I, Al-Umm, Beirut: Daar Al-Kutub Al-Ilmiah, Juz IV, h. 30-32.

${ }^{5}$ Chairuman Pasaribu, Suhrawardi K. Lubis, Hukum Perjanjian Dalam Islam, Jakarta: Sinar Grafindo, 1996, Cet. II, h. 54.
} 
masyarakat Petani. Hal ini menjadi salah satu fenomena khususnya pada masyarakat di Desa Pompengan Kecamatan Lamasi Timur Kab. Luwu. Desa pompengan suatu Desa yang cukup potensial untuk dikembangkan karena didukung oleh luas areal perkebunan sekitar 120 Ha dengan berbagai produksi seperti coklat, jagung, dll hasil per-kebunan sedangkan luas areal pertanian atau tambak sekitar 772 Ha. memiliki luas wila-yah $12.950 \mathrm{~km}^{2}$, dengan jumlah penduduk sekitar 1.241 jiwa dari $244 \mathrm{KK}$, termasuk di antaranya penduduk miskin sekitar $212 \mathrm{KK}$.

Seperti halnya masyarakat Desa lainnya bahwa nilai sosial dan rasa solidaritas masyarakat pompengan masih sangat tinggi dan masih membudaya ditengah-tengah perilaku kehidupan sehari-hari. Nilai-nilai kebersamaan dalam masyarakat ini tercermin seperti halnya dalam kegiatan per-nikahan, aqiqahan, kebersihan lingkungan, membangun, memperbaiki sarana dan pra-sarana umum. Seperti mesjid, pembangunan jalan, dan kegiatan-kegiatan lainnya secara gotong royong. Dengan demikian penduduk desa pompengan masih memiliki nilai-nilai kemasyarakatan yang mencerminkan masya-rakat yang berbudaya dari dimensi kegotong royongan dan kebersamaan dalam menegak-kan kehidupan beragama, ekonomi, sosial, dan budaya.

Meskipun di Desa Pompengan masih ada kelas-kelas sosial, yang membedakan lapisan satu dengan yang lainnya. Lapisan tersebut di antaranya: lapisan masyarakat, buruh perusahaan, petani, pedagang, peng-usaha dan lapisan tokoh agama. Namun tidak ada garis pembatas yang jelas antara kelas sosial sebagai suatu penghalang atau jarak komunikasi, justru sebaliknya meru-pakan mata rantai kebutuhan yang sinergis dan mutualis.

Praktik sewa menyewa telah menjadi sebuah solusi bagi mereka ketika mereka membutuhkan dana. Praktik sewa menyewa yang dimaksud adalah sewa-menyewa kebun dimana pemilik kebun menyewakan kebunnya untuk keperluan modal dan penyewa menyerahkan uang sewanya pada saat terjadinya akad. Adapun harga sewa disesuaikan dengan harga beli pada saat ter-jadinya akad. Sehingga tidak ada pengurangan maupun penambahan harga jika ter-jadi sesuatu baik itu kerusakan kebun maupun jika kebun tidak medapatkan hasil yang banyak. Dalam jangka waktu sewa 
me-nyewa, pemilik tidak bertanggung jawab atas kerugian yang terjadi, misalnya kebun tidak mendapatkan hasil yang banyak atau terjadi kerusakan pada kebun. Dalam jangka waktu tersebut pemilik atau orang yang menyewakan hanya bertanggung jawab me-melihara kebun.

Motivasi menyewakan kebun menurut para "pelaku” umumnya sebagai modal untuk membuka usaha serta untuk memenuhi kebutuhan sehari-hari, ada juga yang menyewakan kebunnya sebagai modal mem-perbaiki rumahnya. Menurut para pelaku, mereka berani untuk berspekulasi menyewakan kebunnya karena hanya itu yang mereka miliki untuk bisa diandalkan mendapatkan uang. Sedangkan bagi para penyewa kebun motivasi mereka selain untuk mencari keuntungan juga karena dorongan untuk menolong para petani karena rata-rata para penyewa adalah petani.

Di dalam Al-Qur'an maupun Al-hadis tidak terdapat larangan maupun kebolehan melakukan sewa-menyewa kebun untuk diambil hasilnya, semusim atau beberapa musim. Dengan tiga dasar hukum yaitu Al-Qur'an, Hadis, dan Ijma' maka hukum diperbolehkannya sewa menyewa sangat kuat karena ketiga dasar hukum tersebut merupakan sumber penggalian hukum Islam yang utama.

Dari beberapa dasar di atas, kiranya dapat dipahami bahwa sewa menyewa itu diperbolehkan dalam Islam, karena pada dasarnya manusia senantiasa terbentur pada keterbatasan dan kekurangan. Oleh karena itu, manusia antara yang satu dengan yang lainnya selalu terikat dan saling membutuhkan, dan sewa menyewa adalah salah satu aplikasi keterbatasan yang dibutuhkan manusia dalam kehidupan bermasyarakat.

Namun jika dilihat dari sifat sewa-menyewa kebun yang spekulatif, artinya tidak adanya kepastian apakah kebun tersebut akan berhasil atau tidak sama sekali menghasilkan dengan jumlah yang banyak atau sedikit, maka unsur ketidakpastian seperti ini tidak dapat dibenarkan dalam hukum Islam. Tidak dapat dipungkiri bahwa transaksi sewa menyewa sudah lazim dilakukan di masyarakat. Seperti yang terjadi di Desa Pompengan Kec. Lamasi Timur Kab. Luwu yang mana sebagian besar masyarakatnya adalah petani dan mereka mempraktikkan sewa menyewa dengan 
kebun sebagai obyeknya. Karena disana kebun merupakan komoditas utama yang menjadi ladang masyarakat mencari rezeki.

Namun ternyata dalam prakteknya sewa menyewa belum dapat terlepas dari berbagai persoalan. Apalagi ditinjau dari Syariat Islam, dalam aktivitas perjanjian sewa menyewa masih terdapat unsur-unsur yang dilarang oleh syara', di antaranya yaitu masih terdapatnya unsur spekulasi (maisir), ketidakpastian (gharar) yang cenderung merugikan salah satu pihak. Adanya unsur-unsur tersebut dalam aktifitas perjanjian sewa menyewa, akan banyak mendatangkan kemadharatan dari pada kemaslahatannya. Hal ini juga akan berakibat timbulnya praktik-praktik ketidakadilan serta berakibat munculnya praktik-praktik kedzaliman yang lain. Oleh karena itu, perlu adanya rekonstruksi sistem operasionalnya. Merekons-truksi sistem operasional sewa menyewa yang ada pada saat ini, dengan menjadikan mekanisme operasionalnya sesuai dengan Syariat Islam maka diharapkan sewa me-nyewa yang selama ini telah berlaku di masyarakat di Desa Pompengan Kecamatan Lamasi Timur Kabupaten Luwu dapat berjalan sesuai dengan tujuan pokoknya.

\section{KONSEPSI SEWA MENYEWA}

Sewa menyewa dalam bahasa Arab diistilahkan dengan "Al-Ijarah", berasal dari kata "Al-Ajru" menurut bahasa artinya ialah "Al-Iwadh". Secara terminologi, para Ulama mendefinisikan secara berbeda-beda. Namun pada prinsipnya sewa menyewa ialah akad yang diadakan oleh pihak penyewa dan orang yang menyewakan untuk memiliki dan mengambil manfaat obyek sewa yang diketahui dengan jelas dan mubah dengan pembayaran imbalan atau harga dengan syarat-syarat tertentu dan dalam periode yang ditentukan. Dengan demikian sewa menyewa mengandung unsur-unsur sebagai berikut : 1) Adanya pihak penyewa dan yang menyewakan, 2) Adanya akad antara kedua belah pihak 3) Adanya obyek sewa yang dapat dipergunakan manfaatnya, 4) Adanya imbalan atau harga terhadap pemanfaatan obyek sewa tersebut, 5) manfaat obyek sewa diketahui dengan jelas dan 6) Dilaksanakan dalam periode tertentu. 
Dalam pelaksanaan sewa menyewa yang diterapkan berdasarkan dari dasar hukum yang ada, menurut para pakar, dasar hukum diperbolehkannya sewa menyewa adalah al-Qur'an, Hadits dan Ijma'.

1. Dasar hukum sewa menyewa dalam Al-Qur'an diantaranya terdapat pada QS. Al-Baqarah (2 : 233) Dan Q. S. Al-Qashash (28: 26-27)

2. Dasar hukum sewa menyewa dalam Hadis yaitu terdapat pada Hadis Rasulul-lah saw yang diriwayatkan oleh Ibnu Majah,"Berikanlah upah kepada orang yang kamu pakai tangannya sebelum keringatnya kering. ${ }^{6}$ Hadist riwayat Ahmad, Abu Daud, dan Nasaiy dari Sa'd bin Abi Waqas menyebutkan: "Dahulu kita menyewa tanah dengan jalan membayar dengan hasil tanaman yang tumbuh disana. Rasulullah lalu melarng cara yang demikian dan memerintahkan kami agar membayarnya dengan uang mas atau perak". 7

3. Landasan Ijma' sewa menyewa

Mengenai diperbolehkannya sewa menyewa, semua ummat bersepakat, bahwa sewa menyewa diperbolehkan. Tidak se-orang ulama pun yang membantah kesepakatan (ijma') ini, sekalipun ada beberapa orang diantara mereka yang berbeda pendapat akan tetapi hal itu tidak dianggap. ${ }^{8}$ Dengan tiga dasar hukum yaitu Al-Qur'an, Hadis, dan Ijma' maka hukum diperboleh-kannya sewa menyewa sangat kuat karena ketiga dasar hukum tersebut merupakan sumber penggalian hukum Islam yang utama.

Dari beberapa dasar di atas, kiranya dapat dipahami bahwa sewa menyewa itu diperbolehkan dalam Islam, karena pada dasarnya manusia senantiasa terbentur pada keterbatasan dan kekurangan. Oleh karena itu, manusia antara yang satu dengan yang

${ }^{6}$ Sayid Sabiq, Fiqhus Sunnah, jilid III, Beirut: Al-Fath Lil I'lam al-'arabi, tt. h. 10.

${ }^{7}$ Ibid.

${ }^{8}$ Hendi Suhendi, op. cit, h. 117. 
lainnya selalu terikat dan saling membutuh-kan, dan sewa menyewa adalah salah satu aplikasi keterbatasan yang dibutuhkan manusia dalam kehidupan bermasyarakat.

Sebagai sebuah transaksi umum, sewa menyewa baru dianggap sah apabila telah memenuhi rukun dan syaratnya, sebagai-mana yang berlaku secara umum dalam transaksi lainnya. Menurut ulama Hana-fiyah, rukun sewa menyewa hanya satu yaitu $i j a b$ (ungkapan menyewakan) dan qabul (persetujuan terhadap sewa menyewa). ${ }^{9}$ Jumhur ulama berpendapat, rukun sewa menyewa ada empat :

1. Dua pihak yang melakukan akad

Dalam hukum Islam orang yang menyewakan disebut dengan "Mu'ajjir", Sedangkan orang yang menyewa disebut dengan "Musta'jir". Kedua belah pihak yang melakukan akad merupakan orang yang cakap bertindak dalam hukum yaitu mempunyai kemampuan untuk dapat membeda-kan yang baik dan yang buruk (berakal) serta dewasa (balig). ${ }^{10}$

\section{Adanya akad (Ijab dan Qabul)}

Akad menurut bahasa berasal dari bahasa Arab " $A l$ - 'Aqdu” yang berarti perikatan, perjanjian dan pemufakatan. Sedang-kan menurut istilah, akad adalah per-talian ijab (pernyataan melakukan ikatan) dan qabul (pernyataan menerima ikatan), sesuai dengan kehendak syari' at yang ber-pengaruh pada obyek perikatan. ${ }^{11}$

Sewa menyewa itu terjadi dan sah apabila ada akad, baik dalam bentuk perkataan maupun dalam bentuk pernyataan lainnya yang menunjuKKan adanya persetujuan antara kedua belah pihak dalam melakukan sewa menyewa, akad tersebut berisi ijab dan qabul. Ijab dan qabul adalah suatu ungkapan antara dua pihak dalam sewa menyewa suatu barang atau benda. Ijab adalah permulaan penjelasan yang keluar dari salah seorang yang berakad dengan menggambarkan kemauannya dalam mengadakan

${ }^{9}$ Abdul Azis Dahlan, Ensiklopedi Hukum Islam, Jakarta: PT. Ichtiar Baru Van Hoeve, 1996, h. 660.

${ }^{10}$ Suhrawardi K.Lubis, Hukum Ekonomi Islam, Jakarta:Sinar Grafika, 2000, Cet I, h. 145.

${ }^{11}$ M. Ali Hasan, Berbagai Macam Transaksi dalam Islam, Jakarta: PT. Raja Grafindo Persada, 2003, h. 101. 
akad. Qabul adalah kata yang keluar dari pihak yang lain sesudah adanya ijab untuk menerangkan persetujuannya. ${ }^{12}$

\section{Sewa atau Imbalan}

Uang sewa atau imbalan atas pema-kaian manfaat barang tersebut disebut dengan "ujrah". Pihak penyewa dan pihak yang menyewakan mengadakan kesepakatan mengenai harga sewa dimana antara kedua-nya terjadi penawaran. Pada dasarnya ujrah diberikan pada saat terjadinya akad sebagai-mana dalam transaksi jual beli. Tetapi pada waktu akad para pihak dapat mengadakan kesepakatan seperti pembayaran boleh di-adakan dengan mendahulukan imbalan atau mengakhirkan imbalan.

\section{Obyek sewa}

Imam Taqiyuddin menjelaskan bahwa tidak boleh menyewakan barang-barang yang tidak bermanfaat atau barang-barang yang dilarang sebab termasuk barang yang batal. $^{13}$

Selain rukun rukun sewa menyewa yang harus terpenuhi dan jelas, syarat sewa menyewa juga harus di perhatikan bagi masyarakat yang ingin melakukan sewa menyewa, adapun syarat sewa menyewa yaitu:

1. Bagi penyewa dan yang menyewakan.

Syarat bagi para pihak yang mela-kukan akad adalah telah baligh dan berakal (menurut mazhab Syafi'I dan Hanbali). Dengan demikian apabila pihak yang ber akad belum atau tidak berakal, seperti anak kecil atau orang gila menyewakan hartanya atau diri mereka sebagai buruh maka akad-nya tidak sah. Berbeda dengan pendapat dari mazhab Hanafi dan Maliki yang menyatakan bahwa orang yang melakukan akad tidak harus mencapai usia

${ }^{12}$ Hasbi Ash-Shiddieqy, Pengantar Fiqh Muamalah, Semarang: PT. Pustaka Rizki Putra,1999. h. 27.

${ }^{13}$ Imam Taqiyuddin Abi Bakr bin Muhammad Al- Husaini, Kifayah Al-Akhyar, Beirut: Daar AlKutub Al-Ilmiyah, tt., h. 400. 
baligh, tetapi anak yang telah mumayyiz pun boleh melakukan akad sewa menyewa dengan ketentuan telah mendapat persetujuan walinya. ${ }^{14}$

2. Adanya kerelaan kedua belah pihak.

Masing-masing pihak menyatakan ke-relaannya untuk melakukan perjanjian sewa menyewa, kalau di dalam perjanjian sewa menyewa terdapat unsur pemaksaan maka sewa menyewa itu tidak sah. ${ }^{15}$ Ketentuan ini sesuai dengan firman Allah dalam surat An-Nisa' ayat 29.

3. Upah atau imbalan

Upah atau imbalan dalam akad sewa menyewa harus jelas, tertentu dan sesuatu yang bernilai harta, hal ini dimaksudkan untuk menghindari terjadinya perselisihan dikemudian hari. Imbalan itu harus ber-bentuk harta yang mempunyai nilai yang jelas di-ketahui, baik dengan menyaksikan atau dengan menginformasikan ciri-cirinya karena merupakan pembayaran harga manfaat. ${ }^{16}$

4. Obyek sewa

Dalam kitab Al-Umm disebutkan bahwa syarat obyek sewa meliputi :

a. Obyek sewa menyewa dapat diserah-kan sebagaimana penyerahan harga (ada serah terima).

b. Obyek sewa menyewa dapat diman-faatkan sampai kepada masa yang disepakati.

c. Manfaat benda dapat dipahami dan dikenal.

d. Penyerahan manfaat obyek sewa harus sempurna yakni adanya jaminan keselamatan obyek sewa sampai ke-pada masa yang disepakati. ${ }^{17}$

\footnotetext{
${ }^{14}$ M. Ali Hasan, op. cit, h. 231.

${ }^{15}$ Chairuman Pasaribu, op. cit, h. 53.

${ }^{16}$ Sayyid Sabiq, op. cit., h 204.

${ }^{17}$ Abi Abdullah Muhammad Bin idris Asy-Syafe'I, Al-umm, Beirut: Darr Al-kutub Al-Ilmiah,
} Juz IV, h. 30-32. 
Hal ini dimaksudkan untuk menghin-dari perselisihan dikemudian hari yang dikarenakan ketidakjelasan dari obyek sewa. Yang dimaksud barang tersebut dapat diserahkan adalah bahwa barang tersebut secara wujud dapat dipindahkan. Maka tidak sah penyewaan binatang yang lari (terlepas), karena tidak dapat diserahkan. Begitu juga tanah pertanian yang tandus dan binatang untuk pengangkutan yang lumpuh, karena tidak mendatangkan kegunaan yang menjadi obyek dari akad ini.

Ulama mazhab Hanafi berpendapat bahwa akad sewa menyewa bersifat meng ikat kedua belah pihak, tetapi dapat dibatal-kan secara sepihak apabila terdapat udzur seperti meninggal dunia atau tidak dapat bertindak secara hukum seperti gila. Jumhur ulama berpendapat bahwa akad sewa menyewa bersifat mengikat kecuali ada cacat atau obyek sewa tidak dapat diman-faatkan. Menurut mazhab Hanafi apabila salah seorang yang berakad meninggal dunia maka akad sewa menyewa menjadi batal karena manfaat tidak dapat diwariskan kepada ahli waris. Menurut Jumhur ulama, akad itu tidak menjadi batal, manfaat menurut mereka dapat diwariskan kepada ahli waris karena manfaat juga termasuk harta.

\section{ANALISIS EKONOMI ISLAM TERHADAP PELAKSANAAN PERJANJIAN SEWA MENYEWA KEBUN DI DESA POMPENGAN KEC. LAMASI TIMUR} KAB. LUWU

Agama Islam adalah agama yang diturunkan oleh allah sebagai rahmat bagi alam semesta. Islam sangat menghargai dan melindungi kepentingan manusia. Pemben-tukan dan pembinaan hukum Islam itu se-jalan dengan kemaslahatan ummat manusia, memberikan manfaat dan memanimalisir kemafsadatan bagi manusia. Oleh karena itu Islam memberikan batasan-batasan dan pola prilaku manusia agar dalam setiap tinda-kannya tidak menimbulkan kemudharatan baik bagi dirinya sendiri maupun bagi pihak yang lain. Dengan demikian diharapkan setiap manusia dapat mengambil manfaat antara satu dan yang lain dengan jalan yang lurus sesuai dengan norma-norma agama tanpa kecurangan dan kebatilan sebagai mana firman Allah swt dalam surat An-nisa'(4:29) 
Muamalah dalam Islam menyatakan bahwa segala sesuatu pada dasarnya boleh untuk dilakukan dengan tujuan untuk kemas-lahatan bersama. Akan tetapi kebolehan ter-sebut dapat juga berubah menjadi sesuatu yang dilarang atau bentuk hukum lainnya apabila terdapat alasan yang mendukung-nya. Ada beberapa alasan yang dapat mengakibatkan perdagangan atau sewa menyewa menjadi suatu yang terlarang jika seandainya hal itu hanya akan menyebabkan dampak yg tidak baik bagi manusia. Kesepakatan dan kerelaan (adanya unsur suka sama suka) sangat di tekankan dalam setiap bentuk per-dagangan (sewa menyewa). Namun hanya dengan kesepakatan dan kerelaan yang ber-mula suka sama suka tidak menjamin suatu transaksi dapat dinyatakan sah dalam Islam yang mengatur adanya transaksi yang di-bolehkan dan tidak dibolehkan.

Dalam agama Islam sewa menyewa merupakan salah satu bentuk kegiatan ekonomi yang berhakikat saling tolong menolong yang ketentuan hukumnya telah diatur. Sebagai suatu akad, sewa menyewa mempunyai rukun dan syarat yang harus dipenuhi sehingga sewa menyewa dapat dikatakan sah oleh syara'. Dalam melakukan kegiatan muamalah, banyak hal yang harus diperhatikan berkaitan sah dan tidaknya akad muamalah yang dilakukan.

Akad yang sah dapat dilihat dari ter-penuhinya rukun dan syarat-syarat akad tersebut. Dalam tahapan transaksi ini dapat dilihat pemenuhan rukun dan syarat sewa menyewa sesuai hukum atau ekonomi Islam, oleh karena itu melalui tahapan ini penulis akan menganalisis beberapa hal termasuk dalam pemenuhan rukun dan syarat sewa menyewa.

1. Orang yang melakukan akad (aqid)

Orang yang melakukan akad disyarat-kan harus berakal dan mumayyiz (minimal 7 tahun), serta tidak di syaratkan harus baligh. Akan tetapi, jika bukan barang miliknya sendiri, akad ijarah anak mumayyiz, di pandang sah bila telah di isinkan walinya. ${ }^{18}$ Syarat lain bagi orang yang melakukan akad adalah adanya kerelaan bagi

${ }^{18}$ Rachmad Syafe'i,, Fiqh Muamalah, Bandung: Pustaka Setia, 2000, h. 125. 
masing-masing, pihak, jika terdapat unsur paksaan maka akad sewa menyewa tersebut tidak sah.

Dalam praktek sewa menyewa kebun di Desa Pompengan Kec. Lamasi Timur Kab. Luwu, rukun diatas telah terpenuhi. Masing-masing pihak yang melakukan akad sewa menyewa adalah orang-orang yang telah baligh dan berakal sehat. Mereka juga mengadakan akad berdasarkan inisiatif mereka sendiri dengan kerelaan dan tanpa paksaan dari pihak lain.

\section{Penetapan upah atau harga}

Harga ditetapkan setelah melalui pro-ses tawar menawar antara kedua belah pihak. Upah atau harga sewa dalam sewa menyewa disyaratkan harus jelas, tertentu dan bernilai harta. Jelas dan tertentu dalam hal ini adalah jelas nilai dari harga sewa tersebut. Hal ini dimaksudkan untuk meng-hindari perselisihan dikemudian hari.

\section{Sighat (ijab dan qabul)}

Ijab dan qabul dilaksanakan oleh kedua belah pihak dengan kata-kata maupun tanpa kata-kata dalam kebiasaan telah diang-gap sebagai persetujuan. Praktek sewamenyewa kebun di Desa Pompengan Kec. Lamasi Timur Kab. Luwu, ijab dan qabul dinyatakan oleh kedua belah pihak dengan kata-kata yang jelas menunjuKKan kesepakatan atau persetujuan diantara mereka. Dalam pemenuhan rukun dan syarat ijab dan qabul dalam pelaksanaan sewa menyewa kebun di Desa Pompengan Kec. Lamasi Timur Kab. Luwu tidak bertentangan ekonomi Islam.

\section{Obyek sewa}

Dari persyaratan tentang obyek sewa di atas, menurut penulis terdapat beberapa syarat yang terpenuhi dalam praktek sewa menyewa kebun di Desa Pompengan Kec. Lamasi Timur Kab. Luwu, dalam praktek sewa menyewa kebun di Desa Pompengan Kec. Lamasi Timur Kab. Luwu, manfaat benda memang dapat di pahami dengan jelas yaitu hasil dari kebun yang menjadi obyek sewa, demikian juga dapat dikenal jenis dan ciri-cirinya.ketiga syarat yang lain menurut penulis tidak terpenuhi pada pelaksanaan akad sewa menyewa kebun di Desa Pom-pengan Kec. Lamasi Timur Kab. Luwu. 
Obyek sewa menyewa yang diisyarat-kan dapat diserahkan sebagaimana penye-rahan harga tidak terpenuhi dalam akad sewa menyewa kebun di Desa Pompengan Kec. Lamasi Timur Kab. Luwu. Penyerahan obyek sewa atau kebun ditangguhkan sampai kebun tersebut berhasil. Selama belum ada penyerahan maka pemeliharaan kebun menjadi tanggungjawab pemilik kebun (orang yang menyewakan kebun), jika kebun tidak berhasil maka tidak ada penyerahan karena pada dasanya yang di ambil dari kebun tersebut adalah hasil dari kebun.

Obyek sewa juga disyaratkan dapat dimanfaatkan dengan sempurna sampai kepada masa yang diseapakati, serta dengan adanya jaminan keselamatan obyek sewa. Syarat ini sangat rentan tidak terpenuhi karena manfaat dari kebun yang disepakati adalah hasilnya. Dalam pelaksaan akad sewa menyewa kebun di Desa Pompengan Kec. Lamasi Timur Kab. Luwu terjadinya akad atau kesepakatan adalah di musim pertama transaksi dimana biasanya sewa menyewa dilaksanakan dua sampai empat kali hasil panen kebun. Penyewa dengan pasti dapat memanfaatkan kebun di hasil panen akad, sedangkan untuk selanjutnya penyewa harus menunggu hasil paenen berikutnya, dimana hasil dari kebun tersebut belum nampak sama sekali dan tidak dapat dipastikan apa yang akan terjadi dengan kebun tersebut di hasil panen kebun mendatang. Apakah kebun tersebut akan mendapatkan hasil ber-ikutnya atau bahkan ada bencana yang dapat merusak tanaman kebun tersebut. Oleh karena itu, terlihat jelas bahwa tidak ada jaminan keselamtan obyek sewa dalam pemenuhan kemanfaatannya. Jika hal ini terjadi maka pihak penyewa akan meng-alami kerugian.

Perjanjian sewa-menyewa kebun di Desa Pompengan Kec. Lamasi Timur Kab. Luwu menunjukkan tingginya unsur ketidakpastian dan spekulasi hasil baik boleh orang yang menyewakan maupun oleh penyewa. Apabila dalam jangka waktu sewa ternyata kebu tidak berhasil, maka pihak penyewa akan menanggung kerugian karena uang sewa telah dibayarkan saat akad. Namun jika dalam jangka waktu sewa tersebut ternyata hasil kebun mengalami kenaikan, maka orang yang menyewakan yang dirugikan. Menurut penulis ada judi dan penipuan, dalam pelaksanaan perjanjian 
sewamenyewa kebun di Desa Pompengan Kec. Lamasi Kab. Luwu. Dalam hal ini mempertaruhkan hasil kebun yang menjadi obyek sewa.

Prinsip bermuamalah adalah member-kan kemanfaatan dan menghindarkan kemu-dharatan sebagaiman kaidah fiqh berikut ini :

$$
\text { لاَضَرَرَارَوَلاَضِرَارًا }
$$

"tidak boleh membuat madharat pada diri sendiri dan tidak boleh membuat madharat pada orang lain."

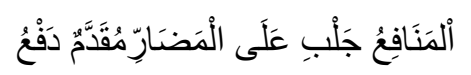

\section{"Menghindari madharat didahulukan daripada mendatangkan Manfaat."}

Dari kedua kaidah fiqh diatas dapat disimpulkan bahwa dalam setiap tindakan manusia harus dihindarkan dari mudharat baik itu diri sendiri maupun kepada orang lain. Unsur ketidakpastian, spekulasi dan indikasi judi dan penipuan yang terdapat dalam pelaksanaan perjanjian sewa menyewa kebun di Desa Pompengan Kec. Lamasi Timur Kab. Luwu dapat dipastikan akan menimbulkan mudharat kepada para pelakunya, terutama para pihak pelakunya yang sangat rentan mengalami kerugian.

Dalam mengakadkan kebun yang dalam hal ini adalah hasil kebunnya, ada beberapa ketentuan yang harus di perhatikan. Sesuai dengan hadis-hadis yang jelas melarang menjual hasil dari tanaman kebun yang belum sampai sempurna, tampak jelas jadinya, dan dapat dipastikan keselamatannya sampai panen. Jika kebun yang di akadkan belum tampak atau ber-masalah, maka akad tersebut mutlak batal. Dalam praktek sewa menyewa kebun di Desa Pompengan Kec. Lamasi Timur Kab. Luwu, manfaat kebun belum tampak sama sekali dan belum bisa diprediksikan kuan-titas dan kualitasnya, selain pembayarannya dilakukan pada saat akad.

Dalam jual beli ijon, buah yang di-akadkan sudah tampak atau minimal sudah muncul buah yang dapat diprediksikan kuantitas dan kualitasnya, pembayarannya juga bisa menggunakan panjar dan sisanya dibayar setelah panen sehingga jika gagal panen masih bisa di musyawarakan lagi untuk mengurangi kerugian pembeli. 
Berdasarkan pendapat madzhab maliki dan hambali yang mengtakan bahwa buah merupakan materi tersendiri dari tanaman hasil kebun, bukan merupakan manfaat kebun yang dapat diakadkan sewa menyewa kebun di Desa Pompengan Kec. Lamasi Timur Kab. Luwu hanyalah pengalihan akad dari jual beli dengan cara mu'awamah yang sudah pasti haramnya.

5. Berakhirnya sewa menyewa

Akad sewa menyewa menjadi batal atau berakhir disebabkan berakhirnya masa sewa menyewa yang telah disepakati kedua belah pihak. Apabila terjadi hal-hal yang tidak di inginkan, seperti terjadi bencana, yang menyebabkan kerusakan kebun yang menjadi obyek sewa tidak berhasil sehingga penyewa tidak dapat mengambil manfaat obyek sewa menyewa sesuai kesepakatan kedua belah pihak.

Menurut ulama madzhab empat, apabila barang yang yang disewakan mengalami kerusakan sehingga penyewa tidak dapat mengambil manfaat dari obyek sewa, maka akad sewa menyewa berakhir dan batal. Dengan demikian, penyewa tidak wajib membayar uang sewa. ${ }^{19}$ Hemat penulis berakhirnya akad sewa menyewa kebun di Desa Pompengan Kec. Lamasi Timur Kab. Luwu tidak sesuai dengan hukum atau ekonomi Islam karena apapun yang terjadi dengan obyek sewa, akad tidak dapat dibatalkan meskipun manfaat obyek sewa tidak dapat terpenuhi.

Dalam pelaksanaan sewa menyewa kebun di Desa Pompengan Kec. Lamasi Timur Kab. Luwu, bila terjadi bencana, kerusakan atau kebun tidak berhasil, maka sesuai kesepakatan pada saat akad kerugian ditanggung oleh pihak penyewa tanpa berhak meminta ganti rugi kepada orang menyewakan. Hal ini tidak sesuai ajaran islam, sebagaimana sabda Nabi Muhammad Saw "Dari Jabir bin Abdillah ra, berkata : Rasulullah Saw bersabda : "jika kamu menjual buah-buahan kepada temanmu kemudian terkena hama, maka tidak halal bagimu memungut pembayaran dari dia.

${ }^{19}$ Abdurrahman Al-Jazairy, Al-Fiqh Ala Madzahib Al-Arba'ah, Terj. Moh. Zuhri et. Al., "Fiqh Madzhab Empat Jilid IV", Semarang:CV. Adhi Grafika, 1994, 263-281. 
Bagaimana engkau akan mengambil harta saudaramu itu dengan jalan yang tidak benar ?" ( H.R. Muslim ).

Hadis tersebut menunjuKKan bahwa tidak halal uang pembayaran akad sewa kebun dimana ada pihak yang dirugikan karena akibat kerusakan hasil panen kebun tersebut dan selayaknya pihak yang dirugi-kan mendapat ganti rugi. Hadis diatas juga melarang mengambil harta orang lain dengan jalan bathil, hal ini sesuai dengan Q.S An-nisa' (4) ayat 29 yang telah diurai-kan penulis sebelumnya.

Sesuai dengan konsep kepemilikan, diantara sebab-sebab timbulnya kepemilikan dari benda yang dimiliki, maka kebun yang dihasilkan dari tanamantanaman kebun yang disewakan adalah milik pemilik kebun dan pemilik kebun tersebut memiliki hak sepenuhnya untuk mentasharrufkan hasil kebun tersebut termasuk mengakadkan sewa menyewa kebun atasnya. Dengan demikian hak sepenuhnya atas hasil kebun tersebut adalah milik dari pemilik kebun yang berhak melakukan apa saja terhadap hasil kebun ter-sebut berdasarkan kerelaannya. Jika dilihat dari sisi ini maka akad sewa menyewa kebun diperbolehkan sepanjang pemilik kebun ter-sebut menyewakan kebunnya berdasarkan kerelaannya. Namun ketika melihat praktek sewa menyewa kebun yang telah dipaparkan diatas mengandung unsur-unsur yang dapat merugikan salah satu pihak, maka meskipun didasarkan kerelaan pemilik kebun ataupun penyewa kebun hendaknya dapat dihindari karena terdapat hal-hal yang bertentangan dengan syara'.

Berdasarkan ketentuan Saddu Adz-Dzari'ah, maka apa saja yang bisa membawa kita kepada mafsadah wajib ditutup. Karena itu, untuk kepentingan preventif, sesuatu yang semula mubah bisa menjadi haram dan dilarang jika sesuatu tadi bisa membawa kepada kerusakan. Melihat praktek sewa menyewa kebun di Desa Pompengan Kec. Lamasi Timur Kab. Luwu yang mengan-dung unsur ketidakpastian, judi dan penipuan, maka untuk mencegah adanya dampak kerugian bagi masyarakat, praktek sewa menyewa kebun di Desa Pompengan Kec. Lamasi Timur Kab. Luwu harus dihindari karena tidak sesuai dengan aturan syara'. 
Pelaksanaan sewa menyewa kebun di Desa Pompengan Kec. Lamasi Timur Kab. Luwu pada tahapan penawaran dan tahapan peninjauan tidak bertentangan dengan keten-tuan hukum atau ekonomi Islam. Dilihat dari motivasi para pelaku dan pelaksanaan tran-saksinya yang dalam tahap ini bisa dilihat pemenuhan rukun dan syaratnya, pada dasarnya praktek sewa menyewa kebun di Desa Pompengan Kec. Lamasi Timur Kab. Luwu tidak sesuai dengan ketentuan syara'. Sebab praktek sewa menyewa kebun di Desa Pompengan Kec. Lamasi Timur Kab. Luwu lebih banyak mengandung unsur mafsadah daripada maslahahnya, sehingga alangkah baiknya jika praktik sewa menyewa tersebut tidak dilaksanakan.

\section{KESIMPULAN}

Pelaksanaan sewa menyewa kebun di Desa Pompengan Kec. Lamasi Timur Kab. Luwu diawali dengan kesepakatan antara orang yang menyewakan kebun dengan penyewa kebun, dimana pihak pertama menyewakan kebunnya kepada pihak kedua untuk diambil hasilnya dalam waktu jangka tertentu. Pihak kedua menyerahkan uang sewa kepada pihak pertama di musim terjadinya akad meskipun hasil kebun yang menjadi manfaat obyek sewa belum tampak. Dalam waktu sewa menyewa, pihak pertama hanya bertanggung jawab untuk memelihara kebunnya, sedangkan jika terjadi kerugian dikarenakan kebun terkena bencana atau tidak berhasil maka pihak kedua tidak ber-hak meminta ganti rugi atau membatalkan akad sewa. Jika hasil kebun berlimpah menyebabkan pihak kedua memperoleh keuntungan banyak, maka pihak pertama tidak berhak meminta tambahan harga sewa atau bagi untung.

Pelaksanaa sewa menyewa kebun di Desa Pompengan Kec. Lamasi Timur Kab. Luwu tidak memenuhi beberapa syarat dalam akad sewa menyewa. Aspek manfaat obyek sewa yang menjadi inti dari sewa menyewa yaitu hasilnya. Sangat rentan tidak terpenuhi karena tidak dapat dipastikan apakah kebun akan mendapatkan hasil panen yang baik atau tidak. Sewa menyewa kebun di Desa Pompengan Kec. Lamasi Timur Kab. Luwu tampaknya mengandung unsur ketidakpastian (gharar), judi , dan penipuan 
yang dalam hukum atau ekonomi Islam dilarang keberadaannya karena dapat merugikan salah satu pihak. Praktik sewa menyewa kebun merupakan pengalihan nama akad dari jual beli mu'awamah karena pada dasarnya yang diambil dari sewa menyewa kebun adalah hasil dan materi tersendiri dari kebun bukan manfaat seperti sewa menyewa pada umumnya. Sedangkan pada saat melakukan akad tidak ada surat perjanjian sewa menyewa antara kedua belapihak. Praktik sewa menyewa Kebun di Desa Pompengan Kec. Lamasi Timur Kab. Luwu lebih banyak mengandung mafsadah dari pada maslahahnya.

\section{DAFTAR PUSTAKA}

Abdul Wahhab Kallaf, 1994. Ilmu Ushul Fiqh, Terj. Moh. Zuhri Ahmad Qarib, Semarang: Dina Utama.

Abdurrahman Al-Jazairy, 1994. Al-Fiqh Ala Madzahib Al-Arba'ah, Terj. Moh. Zuhri et. Al., "Fiqh Madzhab Empat Jilid IV", Semarang:CV. Adhi Grafika.

Abi Abbdullah Muhammad bin Idris Asy-Syafi' I, Al-Umm, Beirut: Daar Al-Kutub AlIlmiah, Juz IV, h. 30-32.

Asnawi, Haris Faulidi. 2004. Transaksi Bisnis E-Commerce Perspektif Islam, Yogyakarta: Magistra Insania Press..

Chairuman Pasaribu, Suhrawardi K. Lubis. 1996. Hukum Perjanjian Dalam Islam, Jakarta: Sinar Grafindo.

Dahlan, Abdul Aziz. 1996 Ensiklopedi Hukum Islam, Jakarta: PT. Ichtiar Baru Van Hoeve.

Departemen Agama, 2005. Al-Qur'an dan terjemahnya, Bandung: CV. Diponegoro.

Ghufron A. Mas'adi. 2002. Fiqh Muamalah Kontekstual, Jakarta: PT. Raja Grafindo Persada.

Hasan, M. Ali. 2003. Berbagai Macam Transaksi dalam Islam, Jakarta:PT. Raja Grafindo Persada.

Hasbi Ash-Shiddieqy, 1999. Pengantar Fiqh Muamalah, Semarang: PT. Pustaka Rizki Putra, 
Bakry, Nazar. 1994. Problematika Pelaksanaan Fiqh Islam, Jakarta: PT. Raja Grafindo Persada.

Imam Taqiyuddin Abi Bakr bin Muhammad Al- Husaini, Kifayah Al-Akhyar, Beirut: Daar Al-Kutub Al-Ilmiyah, $t \mathrm{t}$

Muhammad Ibn Isma'il as-Shun'aniy, tt. Subulus Salam, Beirut: Daar Al-Kitab Al'Arabi.

Suhendi, Hendi. 2002. Fiqh Muamalah, Jakarta: PT. Raja Grafindo Persada.

Suhrawardi K.Lubis. 2000. Hukum Ekonomi Islam, Jakarta:Sinar Grafika.

Syafe'i, Rachmad. 2000. Fiqh Muamalah, Bandung: Pustaka Setia 